\title{
The Very Possibility of a Science of Religion: Ernst Troeltsch and Neo-Kantianism
}

\author{
Peter Woodford / University of Cambridge
}

Ernst Troeltsch appended an intriguing and cryptic footnote in 1912 to an early essay from 1893/94 that was to be republished in a new volume of his collected works, The Christian Worldview and Its Counter-Currents (Die Christliche Weltanschauung und Ihre Gegenströmungen), in which he declared that the intervening years had resulted in "a shift of philosophical standpoint from Lotze and Dilthey to Windelband and Rickert." ${ }^{\text {Troeltsch re- }}$ peated this claim in his late autobiographical essay from 1922, "My Books" (Meine Bücher), which went on to elaborate in greater detail what this shift consisted of. The question of what precisely changed in Troeltsch's outlook has been the topic of much debate, fueled in part by that fact that in both instances Troeltsch immediately qualified his professed "shift" in a manner that left it unclear to what extent, if any, his views were actually aligned with the Baden neo-Kantian school that culminated in Rickert, and that he clearly admired. On the one hand, this question might be considered merely biographical minutia of early twentieth-century German thought. On the other, it concerns a key and foundational problem that continues to arise for scholars of religion as they address the place of philosophy in the field, next to historical, anthropological, and social scientific approaches. ${ }^{2}$ Troeltsch's move from Lotze and Dilthey to Windelband and Rickert signified a new way of understanding the role of normative inquiry and values in scholarship and scientific research. For Troeltsch, and for the Baden school, the problem of normativity more than any other became a point of contact that exposed the fault lines between the sciences, philosophy, and religious thought itself. The

\footnotetext{
${ }^{1}$ Ernst Troeltsch, "Die Christliche Weltanschauung und Ihre Gegenströmungen," in Gesammelte Schriften, vol. 2, ed. Hans Baron (Tübingen: J. C. B. Mohr, 1913), 227.

${ }^{2}$ There have been a number of treatments of this topic, including Robert Pippin, "The Natural and the Normative," Daedalus 138, no. 3 (2009): 35-43; Kevin Schilbrack, Philosophy and the Study of Religions: A Manifesto (Oxford: Wiley-Blackwell, 2014); Thomas Lewis, Why Philosophy Matters for the Study of Religion Ẽ Vice Versa (Oxford: Oxford University Press, 2015).
}

(C) 2017 by The University of Chicago. All rights reserved.

0022-4189/2017/9701-0003\$10.00 
primary goal of this essay is to use the question of the extent to which Troeltsch actually adopted Rickert's theory of normativity to uncover an illuminating episode at the origins of a persisting issue in the field. This episode is especially relevant precisely because it took place during the early period in which a so-called properly scientific study of religion (Religionswissenschaft) was being conceived and established within the academy.

Of course, investigating to what extent Troeltsch turned to Rickert's neoKantianism requires an analysis of what the core views and concerns of Baden neo-Kantianism were. Windelband and Rickert have been labeled by subsequent historians of philosophy as Wertphilosophen (philosophers of value) and normativity theorists, whose central problem was how to make sense of the undeniably normative character of epistemic claims to knowledge and truth within the professed value-neutral, descriptive, and explanatory stance of the natural and historical sciences. ${ }^{3}$ The philosophical debates over norms and values that Windelband and Rickert were immersed in erupted into a controversy over psychologism that came to define a philosophical generation. The psychologism debates involved a wide spectrum of philosophers and seminal figures in the establishment of scientific fields in the German academy - the Marburg neo-Kantians Paul Natorp and Hermann Cohen, Wilhelm Dilthey, founder of empirical psychology Wilhelm Wundt, sociologists Georg Simmel and Max Weber, Franz Brentano, and even the seminal thinker in the formation of analytic philosophy Gottlob Frege, among many others. Edmund Husserl's phenomenology, which later inspired a former doctoral student of Rickert's, Martin Heidegger, also aimed to develop an alternative to psychologistic theories of intentionality and mental representation. ${ }^{4}$ Indeed, it was through the issue of psychologism that these thinkers debated how to make sense of the place of normative inquiry in the emerging effort to generate a scientific study of religion. Troeltsch's footnote on Rickert and the essays he wrote on this newly emerging science of religion positioned him within this wider constellation of thinkers and the epochal problem of psychologism that defined turn-of-the-century academic philosophy in Germany.

These debates over psychologism turned out to be enormously complex and multifaceted, and defining psychologism is a challenge because it was used differently and often polemically by many of its critics. The crucial aspect of the problem that concerns us here began as a question of whether logical rules of inference and reasoning - and even concepts themselves with their attendant necessary and sufficient conditions of application-could be understood as psychological facts about how the human mind functions (is's)

\footnotetext{
${ }^{3}$ See Frederick Beiser, "Normativity in Neo-Kantianism: Its Rise and Fall," International Journal of Philosophical Studies 17, no. 1 (2009): 9-27.

${ }^{4}$ R. Lanier Anderson, "Neo-Kantianism and the Roots of Anti-psychologism," British Journal of the Historv of Philosophy 13, no. 2 (2005): 287-323. Husserl took over Rickert's chair in Freiburg in 1915 after Rickert moved to a position in Heidelberg.
} 


\section{The Journal of Religion}

or if, instead, they contained irreducibly normative, prescriptive content that set criteria for what counts as valid thinking (oughts). While this psychologism problem began by focusing on problems in logic, scientific method, and epistemology, it soon spread to all arenas of human agency and inquiry in which ideal values (Werte) were posited and sought after, including ethics, politics, law, religion, and even aesthetics. If thought and action were regulated by normative prescriptions, the question turned to the problem of what features of the world, if any, could justify their claim to being valid: Where did such principles come from? How could we know them? How could they be justified? Psychologism was the view that the normative authority of prescriptive claims in all areas had to be justified on the basis of facts about subjective psychological processes or even biological drives that they regulated and that were thought to give rise to them in the first place. Critics of psychologism, like Rickert, generally maintained that if norms and values were to be considered to be truly valid, this validity could not depend on whether or not any minds recognized them at all. Valid values, like the external world that our minds aim to represent, must be thought of as genuinely independent of subjective acts of valuing such that we might be wrong about what aims are genuinely worthy to pursue, or what concepts actually capture the phenomena they represent. If this was to be the case, genuinely valid values and norms could not be explained or reduced to facts about natural processes taking place in anyone's psyche or to subjective attitudes shaped by large-scale social and historical processes.

Troeltsch and Rickert both shared the sense that the insights of classical German Idealism, especially Kant and Fichte, finally supplied the intellectual resources for rejecting all of the philosophical schools that they saw to be based on a psychologistic reduction of valid norms and values to natural or historical facts: naturalism, historicism, and materialism. ${ }^{5}$ However, against an astonishingly similar set of background assumptions, both thinkers went in very different directions, and these different directions are especially salient, as I attempt to show here, when one examines how each approached the philosophy of religion. Rickert began as a philosopher of science and methodology and only later applied his conclusions about the place of normativity in science to all areas of "rationally infused" (geistig) activity, in which he included religion. Troeltsch straight away attempted to apply the core insights of Baden neo-Kantianism to challenge underlying philosophical premises of the newly emerging project of a science of religion. Rickert and Troeltsch ended up at positions that were remarkably close, but the points of their divergence are enough to question Troeltsch's genuine

\footnotetext{
${ }^{5}$ Indeed, much of the recovery of Kant and especially Hegel in contemporary philosophy comes from similar concerns over how to understand the relationship between causes and reasons, facts and values, natural events and normative principles, and the metaethical implications of this relationship. See, e.g., the recent collection of essays Naturalism and Normativity, ed. Mario De Caro and David Macarthur (New York: Columbia University Press, 2010).
} 
turn to Rickert's philosophy. The following article explores the nature of Troeltsch's reluctance toward Rickert in order to expose a key problem of continuing theoretical concern, namely, the problem of the legitimacy and character of metaphysics within the scientific enterprise.

The first section of this article presents the main tenets of Rickert's philosophy as characteristic of the Baden school's position on the role of normativity in the sciences. Next, I compare these views to the positions that Troeltsch defended in essays from the first decade of the twentieth century, the period during which he claimed that his shift had taken place. The conclusion that I come to is that despite Troeltsch's profession of a turn to Windelband and Rickert, his continued commitment to the possibility of a metaphysical worldview that was both consistent with and implied by scientific knowledge violated a core premise of the Baden neo-Kantian theory of normativity. Troeltsch's criticisms of Rickert and his own approach to understanding the relationship between is and ought challenged some of Rickert's most basic philosophical commitments. The confrontation between these views serves to remind us that the foundational problem of the ground of normativity - a problem in the study of religion that also emerges in theoretical debates about the epistemological foundations of the social and natural sciences-was crucial to theoretical debates that shaped the emerging discipline.

\section{RICKERT'S NEO-KANTIAN THEORY OF VALUE}

Heinrich Rickert and his mentor Wilhelm Windelband often find a place in the history of philosophy as contributors to the great Methodenstreit between the Natur-and Geisteswissenschaften in Germany during the late 1880s and 90s. In contrast to other thinkers who faced the question of the line of demarcation between the natural sciences and the human sciences, Windelband and Rickert distinguished themselves by drawing this line in purely methodological terms. The natural sciences and the human sciences do not study different kinds of stuff or different domains of reality, let us say mental and physical or action and event, but rather set out with different explanatory aims and different means appropriate to these aims. The "idiographic" human sciences, in particular history, aim to describe and explain individual, nonrepeating events, individuals, movements, and cultural formations, while the "nomothetic" natural sciences aim to discover in particular instances the operation of laws that apply generally and, ultimately, at all places and times. What is often missing from such surveys is the fact that this position on scientific methodology was offered against the background of a confrontation with the fundamental problems of knowledge, mind, truth, and value that have shaped Western philosophy. In contemporary philosophical parlance, we can say that the main concern of this southwest, "Baden" neo-Kantian school lay in metaethics, or metalogic, and centered around the nature of 


\section{The Journal of Religion}

normativity; in the philosophical terminology of turn-of-the-century German thought, it was the problem of understanding the proper relation between das Sein (the is) and das Sollen (the ought).

Rickert's position on this problem took over Kant's pivotal distinction between a quaestio facti and a quaestio juris from the famous "Transcendental Deduction of the Categories" section of the first Critique. For Windelband and Rickert, this distinction was a discovery of the fundamental difference between questions of normative justification and questions of fact, between the irreducibly normative space of reasons governing human thought and agency and the space of causes that govern natural events, which the sciences aim to explain. In this hugely consequential section for both contemporary and nineteenth-century interpreters of Kant, Kant argues that there is a fundamental logical difference between acknowledging the fact that we use certain basic categories - such as substance and accident, cause and effect, necessity and contingency - to render the world intelligible (quaestio facti), and asking what right we have to make normative validity claims, claims to knowledge and truth, using these categories (quaestio juris). ${ }^{6}$ The former is a psychological question that requires, in Kant's terminology, a "physiological" derivation, while the latter is an epistemological question that requires a "transcendental" deduction. ${ }^{7}$

Rickert's basic philosophical move was to insist on the priority of the quaestio juris (the ought) to the quaestio facti (the is) of epistemology to psychology. Not only were matters of fact and matters of normative justification answering different questions, to establish what is the case - even in the realm of the mental-always involves positing a normative value (Wert) or criterion that is presupposed as a value one ought to aim at and that inquiry is directed toward realizing. To see how this claim could be made plausible, it is important to describe the picture of rational agency that Rickert's analysis of scientific methodology rested on. As Rickert claimed in his late programmatic work The System of Philosophy from 1921, "The idea of a science is always the concept of a task to be carried out." ${ }^{8}$ Rickert's subordination of Sein to Sollen was a consequence of his conception of science as an activity carried out by a thinking agent. Like any other act or task, science too presupposed an objective or aim, and this objective was to be found in the value that it sought to realize and the normative criterion it instituted to measure its success or failure. Facts and values could not be separated neatly for Rickert, but this was not because there is no so-called naturalistic fallacy that is committed in logically deriving norms from statements of fact (Rickert believed such purported derivations were not logically valid). Rather, even the most

\footnotetext{
${ }^{6}$ Immanuel Kant, The Critique of Pure Reason, ed. and trans. Paul Guyer and Allen Wood (Cambridge: Cambridge University Press, 1997), 220 [A84/B116-17].

7 Ibid., 220-21 [A85-86/B117-19].

${ }^{8}$ Heinrich Rickert, System der Philosophie: Allgemeine Grundlegung der Philosophie (Tübingen: Mohr-Siebeck, 1921), 153.
} 
basic empirical judgment invokes a normative criterion and involves a commitment to a value that is taken to be normative. ${ }^{9}$ The ought (Sollen) was prior to the is (Sein) because investigating and representing the world is a normgoverned activity guided by a commitment to the value that it seeks to realize.

Rickert articulated these views in his first published work from 1892, Der Gegenstand der Erkenntnis (The object of knowledge). This work was to be a sort of introduction to the basic viewpoint of transcendental philosophy and a demonstration of the normative and value-laden character of knowledge claims in the sciences. Rickert understood his conception of science too as carrying through early insights of Kant, in this case Kant's claim that natural science is oriented by regulative ideals of reason that guide it toward the completion of its investigation of nature. ${ }^{10}$ Rickert envisioned the project of theoretical knowledge, whose tools were the natural and historical sciences, to be guided by the value of truth for its own sake and not as a means to some other end or for the sake of any extrascientific value, whether moral, aesthetic, or religious. The problem with psychologistic theories that considered values to be the product of subjective, psychological events was that such an intrinsic value could not be coherently conceived, so, could not be rationally vindicated either. It could only appear as some kind of subjective projection or illusion over against a valueless physical world, and so the validity of scientific knowledge too crumbled in the face of the materialist picture that threatened values in all other cultural spheres as well.

Rickert's main concern in his writings on epistemology and methodology was to show that understanding our epistemic situation in this way had to be confused. How could knowledge be undermined by a picture of nature that also undermines the very criteria by which this picture has been generated and justified? Rickert's argument against psychologistic and subjectivist theories of value harkens back to ancient attempts to refute skepticism, as he writes that "[a] transcendental ought as the object of knowledge is, regardless of what epistemological standpoint one assumes, indubitable, because it is the presupposition of every true judgment, indeed even every theoretical doubt and thereby the presupposition of every standpoint, with the inclusion of skepticism." ${ }^{11}$ In other words, there is a contradiction involved in denying the value of truth for its own sake, since this denial presupposes the aim of determining facts about the epistemic situation and the distinction

\footnotetext{
${ }^{9}$ Rickert's opposition to the attempt to derive norms from natural events, or anything outside of reason, is evidenced by his criticisms of the movement of Lebensphilosophie. See Heinrich Rickert, Die Philosophie des Lebens: Darstellung und Kritik der Modeströmungen unserer Zeit (Tübingen: J. C. B. Mohr, 1920). I analyze Rickert's criticisms of Lebensphilosophie and the implication that debates over biological sources of normativity had for the philosophy of religion in my dissertation, "Religion, Science, and Value in Nietzschean Life-Philosophy" (PhD diss., Stanford University, 2013).

${ }^{10}$ See Kant, Critique of Pure Reason, 551 [A565/B613].

${ }^{11}$ Heinrich Rickert, Der Gegenstand der Erkenntnis: Einführung in die Tranzendental Philosophie, 5th ed. (Tübingen: Mohr-Siebeck, 1921).
} 


\section{The Journal of Religion}

between getting the world right and getting it wrong. It thereby presupposes recognition of the normative validity of the truth it appears to deny. Of course, by showing that the scientific search for knowledge presupposed a normative value that was not itself a direct object of empirical investigation within the bounds of experience, Rickert also secured a necessary place for philosophy as Erkenntnistheorie within the broader scientific enterprise. Philosophy was charged with clarifying and making explicit the nonempirical, even nonreal (irreal), normative oughts that were presupposed background assumptions of all areas of human activity. The role of philosophy next to the special sciences thus rested on the case against subjectivist and psychologistic theories of value and on the priority of commitment to norms to questions of genesis, origin, history, and cause.

Rickert's legacy in the epochal debates over psychologism was his insistence that the recognition of the objectivity of valid values is a necessary presupposition of thought and agency. As all action involved aiming at the realization of a value, so too did scientific inquiry. Indeed, all of culture was to be understood as the striving toward the realization of values, and the aim of philosophy was to investigate to what extent this striving could be justified. Rickert's view of science as an activity guided by norms gave him a unique angle for investigating the relationship between science and other forms of human activity. He turned to the relationship between science and other spheres of culture, in which he included religion, later in his career as he turned from questions of epistemology and science to the project of a comprehensive system of all cultural values that he explicitly tied to the legacy of Kant. $^{12}$

The core of Rickert's philosophy of religion lay in two sets of distinctions that were fundamental to his philosophical outlook. The first was the distinction between the theoretical value of knowledge enshrined in the sciences and atheoretical values, such as beauty, justice, goodness, and transcendence, that were pursued in nonintellectualist spheres of culture. As we have seen, Rickert offered a transcendental argument to show that the objective value of truth is a logical presupposition of reason. As he turned his attention away from science to other spheres of culture, he argued that one could not provide any such argument for nonintellectualist values. Instead, the element of rational necessity possessed by atheoretical cultural values needed to be understood by linking them to universal structures of practical life. ${ }^{13}$ The epistemological approach to cultural values differed from the naturalist and the genealogical, or historicist, because it viewed the material of cultural history through the idea of some underlying rational structure. Unlike naturalistic Lebensphilosophie, the ideals contained in cultural value

\footnotetext{
${ }^{12}$ Heinrich Rickert, Kant als Philosoph der Modernen Kultur [Kant as philosopher of modern culture] (Tübingen: Mohr-Siebeck, 1924).

${ }^{13}$ Rickert, System der Philosophie, 356.
} 
spheres were not products of biological necessity, vital drive, or function, but rather were products of a necessity that stemmed from the self-legislating capacity of reason. ${ }^{14}$ This is where Rickert's neo-Kantian theory of culture began, especially, to extend Kant's conception of ideals of reason that guide the intellect toward the completion of its search for knowledge to other domains of human activity.

There is not enough space to go into the details of the procedure of Rickert's formal derivation of the nonreal values that constituted ethical, aesthetic, religious, and political life. However, it is necessary to state the overall aim of Rickert's system of values. For Rickert, values could only be considered universally valid if they could be shown to be necessary presuppositions of thought and action. Just as the value of truth could be derived by reflecting on the presupposition of the capacity of representation, he argued that further values could be derived by asking what it would take to fully realize and complete other basic human capacities. As Kant found that reason necessarily sought the unconditioned for every series of conditions in the sphere of knowledge and intellect, so Rickert found that reason sought a full completion of other aspects of human life. For instance, the temporal conditions of action in past, present, and future; the arenas of individual (personal) and social life; and, finally, intellectual and nonintellectual capacities all specified universal parameters of human action and thought to which values must be attached. Redeeming the validity of cultural values required showing how different concrete aims embedded in culture offered the actualization and completion of projects tied to these basic features. For example, Rickert envisioned ethical life as the search for individual self-cultivation and completion; politics sought the social good of a just communal order in which society would achieve its completion; art sought the experience of beauty through intuition; and religion pursued the value of the full completion of all striving in a supra-mundane order. Each of these ideals could be further specified according to the temporal condition in which such realization was sought, namely, in the present, in the indeterminate future, or even in an otherworldly sphere. ${ }^{15}$

The second distinction that Rickert made was between science (Wissenschaft) and worldview (Weltanschauung). The sciences could investigate the sphere of what is (being), but they could not through their own resources make a transition from description and explanation into the normative sphere of the ought. Philosophy can clarify, justify, and derive normative oughts that are presupposed in theoretical science and everyday life more generally, but it too was limited in that Rickert relegated claims about the unity of being and value and about how and whether ideal values can be realized in the existing world to the sphere of faith. For Rickert, this question exceeded the bound-

\footnotetext{
${ }^{14}$ Rickert, Die Philosophie des Lebens, n. 8.

${ }^{15}$ Rickert, System der Philosophie, 379-80.
} 


\section{The Journal of Religion}

aries of the critical reflection on experience and the presuppositions of reason that form the limits of any rational inquiry. Philosophy as an attendant to empirical science was thus left with a dualism that it could not overcome, and although Rickert entertained the idea of a primordial unity of being and value in a proto-physical realm (prophysik) later in his career, he remained staunchly critical of any attempt to resolve this division through reason alone.

Religion always played a dual role in Rickert's thought. On the one hand, it was an atheoretical cultural value-sphere that pursued its own unique value of a final realization and full completion of practical striving. This value, like the values of ethical goodness, aesthetic beauty, and theoretical truth, could be derived in an a priori fashion because, Rickert claimed, it presented a final or ultimate value whose formal content was simply the final completion of the aims of all thought and action, whatever these aims were. On the other hand, religion was a theoretical arena in which a conception of a transcendent, metaphysical unity of being and value, the is and the ought, was proposed. Yet in both theoretical and practical spheres, religion played the role of the cultural arena in which a final realization of the aims of both thought and action, the activities of nonintellectual life and of intellectual understanding, was posited and sought after. Both theoretical and atheoretical spheres pointed toward a final completion of each of their more immediate aims, seeking an unconditioned aim that would encompass and surpass all others.

\section{TROELTSCH AND BADEN NEO-KANTIANISM}

Troeltsch was bitten by the Kantian bug very early in his intellectual development. In his 1922 autobiographical essay "My Books," Troeltsch emphasizes the importance of reading Kant and post-Kantian German Idealist thinkers during his years as a student of theology in Erlangen. ${ }^{16}$ It was not simply admiration of his teachers or nationalist sentiment that pushed him toward the study of the great figures of classical German Idealism-Kant, Fichte, and Schleiermacher - but rather, as he puts it, "the 'vital question' [Lebensfrage] of the right to religious orientation in the face of an all-devouring modern naturalism" that was sweeping the German academy and culture as a whole. ${ }^{17}$ In response to this distinctly "vital" concern brought on by the threat of scientific materialism, Troeltsch's teacher Gustav Class pointed him to the work of the forefather of Baden neo-Kantianism, Hermann Lotze.

The fact that Troeltsch early on turned to Lotze to address his concerns with the mechanistic and materialist picture of nature emerging from the sciences is a telling indication of the steps that led him to Rickert's work, which Troeltsch helpfully narrated in this autobiographical essay. Lotze taught Rickert's

\footnotetext{
${ }^{16}$ Ernst Troeltsch, "Meine Bücher," in Gesammelte Schriften, vol. 4, ed. Hans Baron (Tübingen: J. C. B. Mohr, 1925), 5.

${ }^{17}$ Ibid.
} 
mentor, Wilhelm Windelband, and like Windelband and Rickert, Lotze's aim was to challenge the assumptions behind a commonly held notion that natural science showed normatively valid values and meanings (Sinn) to be an illusion within the blind, mechanistic causal order of the material world. Lotze's strategy to redeem the validity of meaning and value was to challenge the exclusive hegemony of a mechanistic view of nature and to set alongside blind mechanical laws a teleological sphere rooted in goal-directed agency, in which natural ends and purposes could be seen to emerge.$^{18}$ By distinguishing a mechanical sphere of existence or actuality from a teleological sphere oriented by value and validity most pronounced in the living world yet extending to the whole of nature, the mechanistically driven natural sciences and the sphere of the ideal could form mutually exclusive, equally legitimate, "non-overlapping magisteria." ${ }^{19}$ Lotze's strategy thus opposed so-called reductive forms of naturalism by developing a Naturphilosophie in which a sphere of freedom and directed agency coexisted alongside the blind mechanisms that were continually sought by the natural sciences. ${ }^{20}$

As Troeltsch looked back on his life's work in his autobiographical essay, he remarked that both Lotze and philosopher of the human sciences Wilhelm Dilthey at first helped him gain a handle on the limitations of naturalism for studying the ideal contents of human culture that oriented and gave direction to human thinking and acting (Geist). They helped Troeltsch develop a critical foothold against the view of nature that underpinned the Darwinian evolutionists of his day, and Troeltsch traced Lotze's teleological interpretation of the physical world back to Leibniz's "organicist" metaphysics and monadology. ${ }^{21}$ However, in this late essay, Troeltsch stressed again the claim of his 1912 footnote that Lotze and Dilthey would prove insufficient precisely on the point of "the transition from psychological description and analysis to the critical investigation of value [Wert] and truth-content, indeed to the problem of the relationship between psychological analysis and norm-theoretical [gultigkeitstheoretischer] recognition." ${ }^{22}$ Here we can see that

\footnotetext{
${ }^{18}$ For a helpful overview of Lotze's life and writings, see Frederick Beiser's recent study Late German Idealism: Trendelenburg and Lotze (Oxford: Oxford University Press, 2013).

19 This phrase refers to an article by the evolutionary biologist Stephen Jay Gould, who famously defended the claim that religion and science form "non-overlapping magisteria" that do not come into conflict. See Stephen Jay Gould, "Nonoverlapping Magisteria," Natural History 106 (1997): 16-22. Troeltsch and Rickert can be seen as critics of this view, as they both thought that science could undermine the validity of religious claims and, alternatively, that philosophy and philosophical theology could compete with overly reductive pictures from the sciences. Both Troeltsch and Rickert found that the sciences inevitably raised metaphysical and metaethical problems that overlapped with questions central to both philosophy and religious thought.

${ }^{20}$ The importance of Kant's philosophy of biology in his third critique, Critique of the Power of Judgment, which often goes unmentioned in studies of neo-Kantianism, is clearly evident in Lotze's defense of teleology and critique of the mechanistic natural sciences.

${ }^{21}$ Troeltsch, "Meine Bücher," 6.

${ }^{22}$ Ibid., 9.
} 


\section{The Journal of Religion}

Troeltsch's dissatisfaction with psychologism in the theory of value and in epistemology led him to once again affirm his shift toward Rickert's antipsychologistic, transcendental theory of validity. Following this claim, Troeltsch went on to write that his shift was most thoroughly worked out in a variety of essays from the first decade of the twentieth century that dealt with the science and philosophy of religion. These were a lecture held in St. Louis in 1904 on "Psychology and Epistemology in the Science of Religion" (Psychologie und Erkenntnistheorie in der Religionswissenschaft), a short book from 1904 on The Historical in Kant's Philosophy of Religion (Das Historische in Kants Philosophie der Religion), and finally an essay on "Philosophy of Religion" (Religionsphilosophie) published in a Festschrift dedicated to the neo-Kantian Kuno Fischer in 1905, which also contained a piece by Rickert on the philosophy of history. The goal of the rest of this section is to analyze these publications and early essays leading up to them to come to some conclusions about Troeltsch's alignment with Windelband and Rickert.

Between 1895 and 1896, directly following his essay on "Die Christliche Weltanschauung und ihre Gegenströmungen," Troeltsch penned a long essay entitled "The Autonomy [Selbstständigkeit] of Religion" that appeared in three separately published pieces in the Zeitschrift für Theologie und Kirche. ${ }^{23}$ This essay opens with the aim of defending what Troeltsch identifies as an idealist perspective on the problem of the relationship between Geist and Natur, a problem that we might recognize today as a more general formulation of the mind/body problem in the philosophy of mind. ${ }^{24}$ This essay defends what Troeltsch calls an "idealist" thesis that religion is "an autonomous arena of life [Lebensgebiet] that develops and shapes itself out of its own power." ${ }^{25}$ It is misleading to read the motivation behind this claim about the sui generis character of religion as merely defensive in intent without taking into account the general problems in the philosophy of mind that motivate it. For an idealist, in contrast to a materialist, the mind has the capacity to originate, spontaneously, ideas, concepts, and aims of its practical action and striving. Ideas and practices in all cultural (geistig) domains infused with ideal productions of the mind such as art, law, religion, ethics, and even philosophy itself, could not be conceived as straightforward effects of interactions between material things. Instead, these cultural arenas had to be understood as products of the spontaneous capacity of mind to shape itself, to originate, and be bound by, its own content. Here, already, Troeltsch rejects a crude form of naturalistic, causal, explanation of religion - and culture as a whole-by referencing the autonomy of Geist from the domain of mech-

\footnotetext{
${ }^{23}$ Christian Albrecht, editorial introduction to "Selbstständigkeit der Religion," in Ernst Troeltsch Kritische Gesamtausgabe, 20 vols., ed. Friedrich Wilhelm Graf, Christian Albrecht, Trutz Rendtorff, and Gangolf Hübinger (Berlin: De Gruyter, 1998-2015), vol. 1 (2009), 359.

${ }^{24}$ Ernst Troeltsch, "Die Selbstständigkeit der Religion," in Ernst Troeltsch Kritische Gesamtausgabe, vol. 1 (2009), 365.

${ }^{25}$ Ibid., 1:364.
} 
anical causation and arguing that even the representation of Natur is, in part, the product of the mind's spontaneous, productive "power."

In essays following soon after, Troeltsch explicitly applied his idealist framework to critics of religion that were defending an alliance between Darwin and materialism in his milieu, such as Herbert Spencer. In particular, Troeltsch wrote two trenchant essays in which his preoccupation with questions that were at the heart of Baden neo-Kantianism is on full display. The first was an attack on the concessions to materialism in the work of Lotze's student Julius Baumann, published in 1897, entitled "Modern Semi-Materialism" (Moderner Halbmaterialismus); the second, "Haeckel as a Philosopher" (Haeckel als Philosoph), written in 1900, was a criticism of Ernst Haeckel, the controversial popularizer of Darwin in Germany whose books championed the alliance of Darwinism and materialism as the only properly scientific view of the cosmos. The central argument Troeltsch makes against both of these thinkers reiterates his earlier claim about the autonomous character of religion and brings the problem of psychologism into view. While Troeltsch's critique of Baumann is more nuanced, his complaint against Haeckel captures his general criticism of both. Troeltsch writes that Haeckel "never learned to distinguish between psychology and epistemology." ${ }^{26}$ Indeed, if he had, he would not make the mistake of characterizing Denken (thought) as a product of the "mechanical labor of the brain" rather than as "operating only through itself, as determined only by its own norms, completely independent and self-sufficient as the highest judge and proprietor of norms." ${ }^{27}$ Troeltsch's attacks were not directed against Darwin per se, but against philosophers who leaned on Darwin's conception of evolution by natural selection and of humanity's evolutionary origins to defend materialism and psychologistic theories of value.

Troeltsch's claim about the spontaneous and autonomous nature of thought echoed a central premise drawn from sources in classical German Idealism, in particular Kant and Fichte, that also inspired Windelband and Rickert. ${ }^{28}$ Denken cannot be considered as a mere mental event analogous to an event observed in nature with antecedent efficient causes and subsequent effects. Instead, the content of thought had to be considered in part as both the cause and effect of the mind's own intrinsic, productive power. The mind posited and pursued ideas that orient and give content to both action and thought and move it toward a fulfillment and completion of its aims. In these essays, Troeltsch distinguishes between the standpoint of epistemology overagainst psychology through the claim of the autonomy and self-sufficiency

\footnotetext{
${ }^{26}$ Ernst Troeltsch, "Haeckel als Philosoph," in Ernst Troeltsch Kritische Gesamtausgabe, vol. 2 (2013), 789.

${ }^{27}$ Ibid., 2:790.

${ }^{28}$ Rickert in particular was an avid defender of Fichte and wrote trenchant essays in defense of Fichte's articulation of the idealist position and even of Fichte's philosophy of religion that Troeltsch read. See Heinrich Rickert, Fichte's Atheismusstreit und die Kantische Philosophie (Berlin: Reuter \& Reichard, 1899).
} 


\section{The Journal of Religion}

of the normative and ideal contents of thought from investigation of the material and causal conditions in which it occurs. The problem with Baumann and Haeckel, Troeltsch complains, was that their own claims to valid, true, rational, or even scientific thinking were normative claims, not descriptive ones. Yet, it was impossible for any normative prescription to be vindicated on the basis of the purely descriptive and mechanistic stance that these thinkers advanced as the properly scientific worldview. It is an altogether different question to ask how thought works and how it ought to work if it is to achieve the aim of getting the world, and itself, right. Indeed, the fact that many of the claims these materialist Darwinians were making were normative went unacknowledged. Not only did these thinkers fail to reflect on their own normative claims in any rigorous manner, the explanandum of what this normativity consisted in and where it fit within the world of causal interactions between material objects did not come into view. Troeltsch cites Windelband's Präludien in his essay on Haeckel, and he had clearly read Rickert, as an early review of Rickert's Kulturwissenschaft und Naturwissenschaft (The science of culture and the science of nature) from 1899 attests, yet his claim about the autonomy of mind does not indicate any turn away from the less reductive naturalisms of Lotze and Dilthey; the distinctions between psychology and epistemology, while giving early clues of his concerns over a transition from description to evaluation, are not yet indicative of an alliance with Windelband and Rickert's specific version of neo-Kantianism. ${ }^{29}$

Although seeds of overlap with Rickert's theory of validity are present in these earlier essays, Troeltsch did not deeply engage with Rickert's thought until his 1904 essay, "Moderne Geschichtsphilosophie" (Modern philosophy of history). While touching upon broader trends in the philosophy of history, this essay is in essence a lengthy and detailed critical review of Rickert's monumental and still-classic book on the Methodenstreit first published in two parts in 1896 and 1902, respectively, and edited significantly through five later editions, The Limits of Concept Formation in the Natural Sciences (Die Grenzen der Naturwissenschaftlichen Begriffsbildung). In this essay, Troeltsch writes that he "can only express enthusiastic agreement with the basic thoughts of Rickert's work." ${ }^{30}$ The basic thoughts Troeltsch has in mind, he goes on to discuss in turn, are Rickert's emphasis of the difference between psychology and epistemology, his distinction between the amorphous and chaotic flux of historical events and the scientific project of grasping history in concepts, and his emphasis on the distinction between the a posteriori task of accumulating historical knowledge and the a priori task of reflecting on the presuppositions of reasoning. Nonetheless, this essay also makes it clear that as Troeltsch moved from these more general points of agreement to specific characterizations of

\footnotetext{
${ }^{29}$ Ernst Troeltsch, "Review of Heinrich Rickert, Kulturwissenschaft und Naturwissenschaft," in Ernst Troeltsch Kritische Gesamtausgabe, vol. 1 (2009), 527-33.

${ }^{30}$ Ernst Troeltsch, "Moderne Geschichtsphilosophie," in Baron, Gesammelte Schriften, 2:719.
} 
the nature of these a priori principles and the relationship between historical research and investigation into valid values, his stark differences from Rickert began to show.

As Troeltsch struggled with the significance of Rickert's work, he increasingly came to see the crucial weakness of Rickert's transcendental theory of value to lie in its account of the relationship between the real, the given empirical material of cultural and natural history, and the ideal, the normatively valid principles that both thought and agency logically presupposed. In essence, this was the problem of finding the relationship between concrete values of cultural life in its historical development and the normative values that they must be shown to contain if their claims to validity were to be rationally redeemed. Troeltsch's essay frames this as a problem in the philosophy of history, and his objections to Rickert already in this initial confrontation begin to show decisive points of difference that throw into question the wholeheartedness of his "shift." Indeed, this essay shows important steps that led Troeltsch to later pose the problem of "historicism" and its overcoming "through history" in a way that Rickert would never have been able to accept. ${ }^{31}$

"What connection," Troeltsch asks, "is there between the mere concept of valid values generally, the main result of epistemology, and factual historical value-formations, the results of historical research?" ${ }^{2}$ In a crucial passage, Troeltsch complains that

an ultimate aim as the a priori of the epistemological subject signifies only a necessary relation to something universally valid [allgemein-gültiges]. . . . But then nothing is yet said about which actions and which concrete and specific goals lead to this aim. Epistemology can only deduce what is necessary as a formal aim, it can only develop forms of thought and of the setting of ends. Every content of thought and agency stems from experience and from the psychological subject in the streaming diversity of the real. Thus the content of these forms is always directed to experience, and the concept of absolute norms is always directed to history. ${ }^{33}$

Even in this early essay, Troeltsch shows his reluctance to abandon the importance of psychological investigation and a posteriori empirical research in the face of Rickert's strict transcendental method. Troeltsch's objection here to the purely abstract and formal character of Rickert's conception of valid values - despite his clear simultaneous endorsement of Rickert - led him to turn to psychology and history in a way that Rickert all along resisted as succumbing to psychologistic errors. The room that Troeltsch was making here for history and psychology could only appear a nonstarter against Rickert's

\footnotetext{
${ }^{31}$ Ernst Troeltsch, Der Historismus und Seine Probleme, in Ernst Troeltsch Kritische Gesamtausgabe, vol. 16 (2012), 1098

32 Troeltsch, "Moderne Geschichtsphilosophie," 704.

${ }^{33}$ Ibid., 708.
} 


\section{The Journal of Religion}

notion that valid norms could be won if they could be defended as necessary presuppositions of thought and agency — at all places and times — or else not at all. Troeltsch's objection to the overly formal character of Rickert's notion of valid values and his concessions to history and psychology here is an early hint that his profession of a turn to Rickert's neo-Kantianism is not to be taken at face value.

There are further hints in this essay of Troeltsch's reluctance toward key aspects of Rickert's thought. A central question that Rickert left unanswered, for Troeltsch, lay in how the transcendental theory of valid values could orient and inform concrete practical life and decision making. This was the problem of discovering how the epistemological subject, committed implicitly to necessarily valid values, was related to the psychological subject living a concrete life and adopting concrete values in a particular culture at a particular time. The real limitation of Rickert's theory of value became obvious, for Troeltsch, when the directly normative and constructive questions of individual orientation and Lebensführung were posed to Rickert's formal notion of validity. This concern to give a philosophical theory of validity some concrete implications for practical life led Troeltsch to claim in direct conflict to Rickert that "the synthesis of the epistemological and the psychological subjects results always from an act of individual commitment [Überzeugungstat], and it is just this individual character that is part of its ethical value." 34 The bridge between concrete life and the abstract deliverances of philosophy could only be accomplished through acts of individual decision. These acts of individual commitment and "synthesis" gave the rationally necessary, but merely formal, idea of valid values like the abstract value of truth concrete life and actuality in the context of particular cultural formations.

Troeltsch's objection to Rickert in this essay can be characterized as a renewed version of the formalism objection that Hegel and others leveled against Kant's practical philosophy and its supreme moral principle. The mere idea of necessarily valid values, or indeed also of a Kantian categorical imperative, alone is empty unless it can be shown to have been actualized, and to be capable of being acted upon, in the rich configurations of value and the concrete ideals of collective life in history. Of course, Rickert never intended his transcendental epistemology to yield such concrete content and he strictly distinguished, for this reason, between the transcendental task of philosophy, the task of positive science, and the task of nonintellectual life more generally. Philosophy could not yield concrete norms for how the sciences investigate nature, nor for how individuals ought to pursue self-cultivation in their ethical lives, but merely to redeem the sense in which these formal aims were genuinely valid despite the deliverances of the natural and historical sciences that appear to indicate the contrary. Troeltsch's dissatisfaction with this abstract and purely theoretical character of philosophy led him to abandon

${ }^{34}$ Ibid., 712. 
one of Rickert's most important principles, namely, his a priori transcendental method.

This early essay shows that it was Troeltsch's aim to give the theory of normativity concrete content, such that it could conceivably shape cultural practices and guide individual living, that would to give the empirical study of culture and history normative significance for life. Troeltsch even offered an alternative conception of how science and philosophy could inform and even fashion concrete values in a way that transgressed the purely theoretical role that Rickert relegated them to. Troeltsch argued that "the effort to base one's judgment upon the broadest basis, to maintain continuity with everything that has been achieved, and to decide on the basis of sober comparisons: These determine the scientific character of such a judgment, but the scientific character does not eliminate the individuality of such a decision." 35 The "scientific" character of such a project consisted in its procedure and its intent, but Troeltsch admitted that this could not override the fact that any such judgments maintained an irremovable residue of individuality, decision, and therefore extrascientific interest. This mixture of scientific and extrascientific aims would override Rickert's distinction between the task of science to pursue truth for its own sake and the values embedded in nonscientific spheres. It also challenged Rickert's notion that normatively valid values had to be derivable from universal features of agency; Troeltsch's individualist residue could only undermine their claim to genuine validity.

Finally, Troeltsch's initial engagement with Rickert showed that although he was deeply persuaded by the necessity of the epistemological standpoint next to psychology, it did not go far enough. At the end of Troeltsch's critical essay, he gestures in the direction of a resolution to the problem of psychologism that goes further beyond Rickert's transcendental epistemology than the points previously mentioned. He writes that "despite all cautious formulation, the combination of the psychological and the epistemological subject is in truth a metaphysical problem." 36 While Rickert hoped to provide a theory of normativity based on the presuppositions of rational agency alone, Troeltsch complained that this was inadequate. Troeltsch does little in this essay to fill out the idea of metaphysics that he has in mind or to give a detailed argument for the necessity of this turn to metaphysics, but it is clear that he comes to think that no resolution of the relationship between the transcendental and the empirical, the epistemological and the psychological, the ought and the is, would be possible without venturing forth into the troubled waters of metaphysics. ${ }^{37}$ This was of course a clear and conscious

${ }^{35}$ Ibid.

${ }^{36}$ Ibid., 728.

${ }^{37}$ A similar argument against Rickert has recently been advanced by Benjamin Crowe in "Faith and Value: Heinrich Rickert's Theory of Religion," Iournal of the History of Ideas 71, no. 4 (2010): 617-36. Like Troeltsch, and others of Rickert's generation, Crowe argues that Rickert's theory of normativity is insufficient without a metaphysical foundation of some sort. 


\section{The Journal of Religion}

step beyond the confines of Rickert's theory of normativity, a step beyond Kant.

In the years immediately following Troeltsch's essay on Rickert's Grenzen, he worked on the collection of essays on the philosophy and science of religion that allegedly carried through his turn to Rickert's theory of validity, and an analysis of these can allow us to come to some more bold conclusions concerning the extent of Troeltsch's turn to Rickertian philosophy. In keeping with his attention to the theme of psychology and epistemology, Troeltsch declared in his lecture delivered to a US audience at the St. Louis Louisiana Purchase exposition in 1904 during a session entitled "Contemporary Problems in the Philosophy of Religion" that "psychology and epistemology will always be the fixed core of the science of religion, both conceived in the relation that Kant fundamentally assigned them." 38 This lecture was an appreciative but critical response to William James's famous 1901-2 Gifford Lectures later published as The Varieties of Religious Experience, and one of the first and most influential responses to James's psychology in German academic theology. ${ }^{39}$ The main message of this lecture was very clear: James's assemblage and arrangement of psychological data were massive scientific achievements, but they were incomplete without analysis in light of Kant's insistence on the crucial role of epistemology and normative inquiry next to the descriptive sciences. Troeltsch insisted that his Kantian critique of what he saw as James's characteristically American contribution to the philosophy of religion was not an artifact of nationalist sentiment or allegiance. Instead, it came from the realization that he later claimed turned him in favor of Rickert's theory of transcendental validity, namely, that if science "demands above all empirical knowledge of the phenomenon [of religion], it does so of course only to be able to answer the question of truth-content on the basis of this knowledge ... and the question of truth-content is always a question of the valid [das Geltende]." 40

The theory of normativity entered into discussion precisely when it came to evaluating claims to truth and knowledge, and such claims were made not only by scientists but of course by religious practitioners themselves. Although Troeltsch found James's work to be an incredible achievement, he complained that psychology "analyzes, generates types and categories, shows relatively constant connections and interactions. But just here lie the limits of such a psychology, which can be endlessly expanded in its descriptions, but can never advise us on the validity and truth-content through its own resources. For the science of religion this cannot be the last word." ${ }^{41}$ Or, again, "The valid

\footnotetext{
${ }^{38}$ Ernst Troeltsch, "Psychologie und Erkenntnistheorie in der Religionswissenschaft," in Ernst Troeltsch Kritische Gesamtausgabe, vol. 6 (2014), 236.

39 Trutz Rendtorff, editor's introduction to "Psychologie und Erkenntnistheorie in der Religionswissenschaft," in Ernst Troeltsch Kritische Gesamtausgabe, vol. 6 (2014), 207.

${ }^{40}$ Ibid., 6:227.

41 Ibid.
} 
cannot be determined through the accumulation of factual phenomena or through the arbitrary determination and establishment of something factual, but only through recourse to universally valid concepts, inherent in thought or reason." ${ }^{42}$ Troeltsch went on to position these points on the problem of the normativity of knowledge within a broad history of Western thought; he considered himself, and Rickert, to be reviving the central spirit of rationalism from Plato, Spinoza, Leibniz, and Descartes over against the empiricism of Hume, Locke, and William James. However, the problem that immediately presented itself once the distinction between psychology and epistemology, empiricism and rationalism, was properly recognized was how to understand the relation between these two distinct forms of inquiry. Once again, as Troeltsch ventured beyond mere recognition of the difference between description and evaluation and more deeply into the philosophical details of how these relate, his decisive differences with Rickert emerged.

Troeltsch's essay on Rickert's Grenzen indicated his departure from Rickert through the formalism objection and the necessity of metaphysics, and his essay on the science of religion augmented these points with the further criticisms. He labeled Rickert's Kantian position an experience-immanent (erfahrungsimmanent) rationalism, which aimed to arrive at universally valid values by reflecting on the conditions of the possibility of experience, rather than deriving them from pure thoughts or through observation of natural objects given to the senses. Troeltsch affirmed this approach and its method to sift through and dig beneath the manifestations of thought and agency to discover the rational principles that were latent in them. However, Troeltsch added that "epistemological norms are different from merely psychological facts, but can only be retrieved from them ... psychology is the entranceway to epistemology." ${ }^{43}$ If we take the example of the value of truth that was central to Rickert, we might interpret Troeltsch's claim here to be that there is a difference between the psychological act of valuing truth and the epistemological effort to redeem this value as genuinely valid. This much is in keeping with Rickert's basic conception of philosophy. But Troeltsch goes on to say that redeeming this value is a matter of "retrieving" it from psychological investigation. It is unclear whether or not Troeltsch's aim here was to rationally reconstruct Rickert's views, but this statement is a clear departure from Rickert's transcendental method, which sought to justify the validity of different values - such as the value of truth — not by first studying what is valued by various agents but by reflecting on necessary presuppositions of thought and action.

Of course, Troeltsch's lecture was on the contribution of William James's Varieties, and for an American audience he was keen to acknowledge this contribution to philosophy of religion. But in acknowledging here that psycho-

\footnotetext{
42 Ibid., 6:228.

${ }^{43}$ Ibid., 6:240.
} 


\section{The Journal of Religion}

logical description has any implication for normative analysis, or in his essay on Rickert that historical research has any role for determining valid values, Troeltsch conceded ground to empiricism that Rickert strictly denied. Indeed, Rickert's book-length, scathing critique of life philosophy (Lebensphilosophie) written in 1920 entitled Die Philosophie des Lebens: Darstellung und Kritik der Philosophischen Modeströmungen unsrer Zeit (The philosophy of life: presentation and critique of the fashionable philosophical trends of our time), explicitly rejected Troeltsch's point about the necessity of psychology in considering the problem of valid values. ${ }^{44}$ Rickert saw Lebensphilosophie to be represented most starkly by Wilhelm Dilthey, Georg Simmel, Friedrich Nietzsche, and various naturalists and Darwinists of all stripes, but he also counted William James among the Lebensphilosophen in this book. He argued that James committed the same fallacy as all other subjectivist, psychologistic, and naturalist theorists of normativity in that he reduced rationally undeniable values that were constitutive of scientific inquiry itself into facts about natural drives and psychological states and so failed to appreciate the necessity of a transcendental standpoint on the problem of normative validity.

In addition to reiterating the importance of empirical research for inquiry into validity, Troeltsch's lecture also fills in the metaphysics that he gestured toward in his earlier review of Rickert. He argues that it is precisely mysticism that holds the key to both the universal and rational element of religions as well as the synthesis of the epistemological and psychological subjects. In mystical experience, an a priori element of consciousness is actualized in a way that unifies the sphere of rational validity and the psychological stream of consciousness. Troeltsch even goes so far as to say that mystical experience manifests the "great unsolvable basic mystery of life, that is always active but never grasped," that it is the "hidden unity of cosmic reason" or the "effect of the divine, creative original power, which is the embodiment of what is and what ought to be." ${ }^{45}$ He gestures here again to Rudolf Eucken's conception of a "noologie," a cosmic ground and underlying unity to both reason and nature that Rickert's strict separation between "real" being and "nonreal" values could not conceive. ${ }^{46}$ For Troeltsch, there was an underlying metaphysical unity between the individual and the supra-individual, behind reason, nature, history, and life. Here too, Troeltsch sees normatively valid values as being produced and actualized by psychological subjects in history, and this production was itself to be understood as a manifestation of an underlying metaphysical unity, the divine life, that encompassed both reason and nature.

\footnotetext{
${ }^{44}$ Troeltsch cites Rickert's book on Lebensphilosophie in the footnotes of the sections on Baden neo-Kantianism in Troeltsch's Historismus but does not explicitly discuss it.

${ }^{45}$ Troeltsch, "Psychologie und Erkenntnistheorie," 251-52.

${ }^{46}$ Thanks to Brent Sockness for indicating the importance of Rudolf Eucken and Leibniz's monadology for understanding Troeltsch's metaphysics and the issues that divided Troeltsch and Rickert.
} 
Troeltsch's lecture offers evidence to support two main conclusions about his stance toward Rickert that remains consistent throughout the essays from this period, including his essay on "Philosophy of Religion" and his short book on Kant. Troeltsch clearly took from Baden neo-Kantianism an emphasis on the division between description and normative analysis, between the investigation of facts and causes and the task of seeking reasons and justifications. However, this basic point is not sufficient to constitute a full endorsement of Rickert, nor would it unambiguously place Troeltsch within any of the turnof-the-century neo-Kantian or late-Idealist factions. While this point is important for the cases being made by various neo-Kantians concerning psychologism, Troeltsch's acceptance of this difference is not enough to justify his claim to have adopted Rickert's strict antipsychologistic position. The crucial claim of Rickert's philosophy was not merely distinguishing philosophy from science and arguing for the necessity of normative analysis alongside science, but also arguing that the empirical sciences were not relevant for inquiry into the validity of values. The import that Troeltsch gave to psychology and history in his work from this period and for the task of normative analysis was a clear departure from the more strict division between quid facti and quid juris that marked Rickert's thought. The second conclusion is naturally that Troeltsch's turn to metaphysics as a solution to Rickert's dualism between the is and the ought also departed from a defining feature of the Baden neo-Kantianism. Even though Rickert's late writings hint at a metaphysical unity of being and value, he consistently considered speculations about this unity to be beyond the bounds of what could claim the universality and normative necessity of reason, of science, and of the sphere of knowledge.

Troeltsch was not alone in making these criticisms of Rickert. Indeed, Rickert's student Emil Lask, who has been found to be influential for Heidegger's own dismissal of neo-Kantian value theory, made a similar complaint against Rickert that his dualism of Sein and Sollen required an ontological resolution. ${ }^{47}$ Much dissatisfaction with Baden neo-Kantianism has resulted from its strict dualism between being and value, psychology and epistemology. Troeltsch's rejection of the finality of this dualism came in part from his insistence on the need for philosophy and science to contribute to validating concrete, and not merely formal, cultural values. Troeltsch considered the scientific procedure for arriving at an individual "synthesis" of cultural values as a metaphysically loaded act, one that performed and reenacted the unification of the normative space of reasons and the natural space of causes that characterized the underlying cosmic unity of Geist and Natur itself. Through the act of individual commitment, each individual personality became a microcosm of the whole of nature and history and its underlying unity. In the essays

${ }^{47}$ See Theodore Kisiel, "Why Students of Heidegger Will Have to Read Emil Lask," Man and World 28 (1995): 197-240. 


\section{The Journal of Religion}

mentioned here, Troeltsch refers to a recurring group of figures and ideas he has in mind who equally rejected Rickert's strict dualism, including Henri Bergson's vitalist elan vital, Rudolf Eucken's concept of a "noologie" that provided a metaphysical source of both mind and nature in a cosmic nous, and even Lotze's teleological Naturphilosophie. ${ }^{48}$ In very early and late writings, including his retrospective "My Books," Troeltsch refers to Leibniz's "organicist" monadology as providing the final, rationalist metaphysical resolution of the unity of human rationality and nature and of psychology and epistemology. ${ }^{49}$ Troeltsch's continuing alignment with these thinkers signifies, in the end, that his turn to Rickert was only ever half-hearted.

\section{TROELTSCH, RICKERT, AND THE VERY POSSIBILITY OF A SCIENCE OF RELIGION}

This reconstruction of Troeltsch's development in relation to Rickert has shown how his early concern over whether a religious stance could be justified in the face of a reductive naturalism coming from the sciences left him embroiled in the debates over psychologism that defined his generation. Troeltsch's declaration of his transition from Lotze and Dilthey to Windelband and Rickert, perhaps unwittingly, revealed a moment at which he became entangled between competing, and by many lights, incompatible philosophical schools on the psychologism problem. Lotze and Dilthey represented a diffuse set of thinkers that Rickert in 1921 came to designate as vitalist Lebensphilosophen, who held that normative values both originated in and could be justified only in relation to life, understood as historically dynamic, prereflective natural impulses, desires, and drives. Rickert represented the complete opposite, a philosopher who rejected completely any naturalist or metaphysical foundation of normativity and who saw values as aims presupposed by both thought and structural features of rational agency.

In a sense, Troeltsch's Auseinandersetzung with Rickert and Windelband can be captured simply as a quarrel over whether or not a nonpsychologistic theory of normativity could stop with the transcendental argument that valid norms are always presupposed by reason, or rather had to rest further on an underlying, metaphysical conception of the unity of Geist and Natur. Troeltsch's move to metaphysics was of course a decisive break with both of the neoKantian schools. Here we might think that we end up back at Kant versus Schleiermacher, Hegel, or Schelling and the question of critical versus precritical metaphysics. Yet these different assessments of the possibility of metaphysics resonated throughout each thinker's conception of how valid values

\footnotetext{
${ }^{48}$ Troeltsch, "Psychologie und Erkenntnistheorie," 252.

49 Troeltsch, "Meine Bücher," 10.
} 
were to be discovered and defended. On the one hand, Troeltsch continued to hold that concrete valid values in all cultural spheres had to be achieved through a complex, and even individual, wrestling with empirical material of cultural history that had to maintain a fundamentally irrationalist residue. Rickert, on the other hand, maintained the staunch rationalist view that if the values found in cultural activity were to make a claim to objective validity, their formal goals had to be capable of being derived through a purely a priori and rational procedure.

Despite the conclusions reached here that Troeltsch's philosophical commitments transgressed the principles of Baden neo-Kantianism that he aligned himself with, I hope also to have shown that Troeltsch's unique positions must be understood as a critical response to Rickert and to basic problems that they shared in common. Indeed, Troeltsch's resort to theistic metaphysics can only be understood in relation to an antipsychologistic division between the is and the ought, between psychology and epistemology, that he shared with Rickert and that was the defining problem of this generation of German philosophers. Troeltsch's philosophy of religion, or philosophical theology, was finally an attempt to overcome the dualism between normativity and nature, natural drives and valid values, that plagued turn of the century attempts to defend the role of philosophy next to the natural sciences.

I would like to close by placing this debate in a broader context. Troeltsch's dialogue with Rickert is a local example of the problems of mind, normativity, rationality, and the nature of science itself that attended the conception of a Religionswissenschaft at its origins. Debates over these problems were spread across the university and had implications for the foundations of many emerging and still young disciplines, including psychology, economics, sociology, and anthropology. Rickert and Troeltsch both defended the core claim that science necessarily, indeed as a matter of achieving its core aims and defending its own presuppositions, raised questions that we today would regard as metaethical and, controversially, even metaphysical. Indeed, religion presented unique problems as an object of scientific study precisely because religions themselves advanced ethical, metaethical, and metaphysical claims taken to be normative that could be studied only by paying attention to their reasons in addition to their causes. Rickert and Troeltsch are instructive for contemporary debate not only for their particular views and their identification of fundamental problems but because they show that determining what science, philosophy, and religion are and what boundaries exist between them is itself a theoretical task that raises fundamental problems of mind, knowledge, nature, and value that cannot be avoided. In other words, reflection on the science of religion calls for philosophy understood as the attempt to arrive at normative, valid, even correct positions on these issues. More speculatively, these thinkers suggest to us, against the grain of much contemporary theorizing, that when fields of inquiry are themselves understood as 


\section{The Journal of Religion}

goal-directed tasks that are committed to normative principles and thus are required also to investigate the ground of these normative principlesas both Rickert and Troeltsch understood them to be- the scientific aim, the aim of philosophy, and the aim of religious thought do not need to be considered in conflict. 